\title{
Social Work and Human Rights_-Linking Two Traditions of Human Rights in Social Work
}

\author{
Silvia Staub-Bernasconi ${ }^{1}$
}

Published online: 21 March 2016

(C) Springer International Publishing 2016

\begin{abstract}
Mostly unknown in Europe and perhaps also in other regions of the world is that social work has a tradition of human rights of more than 100 years - first present in writings, second as accounts of and about human rights activists and then getting "institutionalised" in many common documents of the International Association of Schools of Social Work (IASSW), the International Federation of Social Workers (IFSW) and the International Council of Social Welfare (ICSW). In 1988, an International Commission on Human Rights was established. These topics will be the focus of Part I, putting the main emphasis on writings of Jane Addams. As the documents of the three international associations had to be written on a very general, abstract level, I try to show the practical relevance of them for three professional areas, namely first the common ground and overlapping of the client population of social work and the one of the UN called "vulnerable individuals and groups", second the consequences of the General Statement about "Ethics in Social Work" according the professional mandate with human rights and social justice as central ideas. Third, one can interpret the addition of social justice in the international definitions of social work as a wise restriction of social work to the "social" aspects of the profession, meaning especially social problems and social rights. This special focus will be exemplified in Part II, referring to the European context with a special focus on
\end{abstract}

Silvia Staub-Bernasconi

staubernasco@bluewin.ch

1 Technical University Berlin, 10623 Berlin, Germany
Switzerland and Germany. It describes two projects developed by students, now alumni of the Berlin Master of "Social Work as Human Rights Profession". The first one has the goal of ratification of the European Social Charter of Social Rights of 1996 by the Swiss parliament; the second one shows how to use the UN instrument of Universal Periodic Reviews in the case of poverty and social rights. The article closes with some general guidelines for the further integration of human rights as elements of social work as (critical) profession.

Keywords Human rights tradition in social work · Vulnerable individuals and groups $\cdot$ Social rights $\cdot$ Triple mandate . Human rights activism · European projects

\footnotetext{
"It is well to remind ourselves from time to time that 'Ethics' is but another word for 'righteousness', that for which many men and women of every generation have hungered and thirsted and without which life becomes meaningless."
}

"To attain individual morality in an age demanding social morality, to pride one's self on the results of personal effort when the time demands social adjustment, is utterly to fail to apprehend the situation.”

"What's all the talk about fraternity and equality, when one doesn't have the right to make it concrete in the helping relationship?"

(Jane Addams: Democracy and Social Ethics, 1902, p. 1, 2f., 11) 


\section{Introduction}

Mostly unknown in Europe and perhaps also in other regions of the world is that social work has a tradition of human rights of more than 100 years - first present in writings, second as accounts of and about human rights activists and then getting "institutionalised" in many common documents of the International Association of Schools of Social Work (IASSW), the International Federation of Social Workers (IFSW) and the International Council of Social Welfare (ICSW). In 1988 an International Commission on Human Rights was established (Staub-Bernasconi 2012b).

These topics will be the focus of Part I, putting the main emphasis on writings of Jane Addams. As the documents of the three international associations had to be written on a very general, abstract level, I try to show the practical relevance of them for three professional areas, namely first the common ground and overlapping of the client population of social work and the one of the UN called "vulnerable individuals and groups", second the consequences of the General Statement about "Ethics in Social Work" according the professional mandate with human rights and social justice as central ideas. Third, one can interpret the addition of social justice in the international definitions of social work as a wise restriction of social work to the "social" aspects of the profession, meaning especially social problems and social rights.

This special focus will be exemplified in Part II, referring to the European context with a special focus on Switzerland and Germany. It describes two projects developed by students, now alumni of the Berlin Master of "Social Work as Human Rights Profession". The first one has the goal of ratification of the European Social Charter of Social Rights of 1996 by the Swiss parliament; the second one shows how to use the UN instrument of Universal Periodic Reviews in the case of poverty and social rights. The article closes with some general guidelines for the further integration of human rights as elements of social work as (critical) profession.

\section{Part I: Human Rights in Social Work-a Long Tradition}

Great ideas, regressive-destructive or progressive-constructive ones, do not fall from heaven. They have a history which starts many times with a book or written manifest. This was so with the writings of philosophers of the Enlightenment (Hugo Grotius, Thomas Hobbes, John Locke, Jean-Jacques Rousseau, Thomas Paine, etc. as forerunners of the Bill of Rights in the USA and the French Declaration of Human Rights of 1789. But the written tradition goes back to the Bible, the Koran, the thesis of Martin Luther, and continues with "The Capital" of Karl Marx, "Mein Kampf" of Hitler, the Freedom Charter of the African National Congress, the writings of Mahatma Gandhi, Martin Luther King, Nelson Mandela and many others). So it makes sense to look for texts in the tradition of social work which have a reference to human rights and possibly inspired human rights activists and social movements and subsequently the discussion and institutionalisation in binding, consensual documents or even legislation.

\section{A Short Trip into the History About Social Work and Human Rights}

So I was wondering if we can identify in social work-although on a very much less famous and pretentious level-a similar process. Looking for early texts about theoretical pioneers in Europe and worldwide, I was not very successful. Alice Salomon in Germany, the founder of the AliceSalomon University of Applied Sciences, wrote extensively about the problems and necessities of social politics and policy especially referring to poverty - the poor and their families - and to the discrimination of women, but without reference to human rights. Yet, one could say that she was a forerunner in relation to human rights as social rights and implementation of social justice. The same holds for Ilse Arlt in Austria, who developed a theory of poverty defining it as the inability to satisfy biological, psychological, social and cultural needs and thus being deprived of a state of well-being. In fact, till now, I found only pertinent passages in three books of Jane Addams (see below).

The situation is somewhat better concerning human rights activists: In England, there was Eglantine Jebb who after World War I drafted a Charter of the Rights of the Child which was ratified in 1924 by the assembly of the League of Nations in Geneva. As war violates all human rights, one could say that the Women's International League for Peace and Freedom founded 1919 in Zurich with Jane Addams as its first president is another example. With one of the first offices as an NGO accredited at the UN in Geneva, it succeeded in its goal to support the women's peace activists with an organisation.

Further activists with a clear reference to human rights were Bertha Capen Reynolds; Sattareh Farman Farmaian, the founder of the School of Social Work in Teheran; Whitney Young as a prominent black leader of the Civil Rights Movement in the USA; Winnie Mandela being banned and imprisoned countless times during her fight against the Apartheid Regime in South Africa; and Rajagopal P.V. in India, calling himself a social worker-who leads a social movement of Dalits and Adivasi called "Ekta Parishad" claiming land and water rights, social justice for an honourable existence and fighting against big, land-grabbing corporations in the non-violent tradition of Gandhi.

I am sure that there are many unknown social workers risking and losing their job and life in engaging themselves 
for the rights of their clients (Ramon 2008). I am also fully, painfully aware that this account is extremely incomplete and does not mention texts and activists in many other countries of the world. This fact alone would justify an intensive research project to get a picture about historical preliminaries of the idea of human rights in social work before its institutionalisation in the documents of the three international associations of social work. One can date the start of the institutionalisation phase with the publication of the text Teaching and Learning about Human Rights. A Manual for Schools of Social Work and the Social Work Profession by the United Nations Centre for Human Rights in cooperation with the IFSW and the IASSW, New York: Human Rights in 1992 (re-published in 1994). Since then, human rights have played an important role in the main documents of the international associations, for example, the International Definition of Social Work, Ethics in Social Work, Global Standards for the Education and Training of the Social Work Profession and the newest one: "The Global Agenda for Social Work and Social Development—Commitment to Action" (2012).

\section{Three Texts of Jane Addams Introducing the Idea of Human Rights in Social Work on the Community, National and International Levels}

The writings of Jane Addams deserve special attention for the introduction and relevance of human rights in social work. She is known as the founder of the Hull House Settlement in Chicago together with her friend Ellen Gates Starr in 1889. I restrict my analysis to three books.

In Democracy and Social Ethics (1902), she develops the idea of "integral democracy", claiming democracy not only in politics but also in the family, the industry, as well as the educational system. The text starts with a long chapter about "Charitable Effort" (p. 13-70) which criticises the feudal structures that had survived in the charitable relationships between the friendly visitors and the persons in need of financial help. She asks what is the legitimation to force a mother to work under miserable conditions for herself and her children, while the friendly visitor lives at home on the income and fortune of her husband? What is the legitimation to force young women to save money from their miserable wage instead of buying cheap jewellery and nice clothes with the hope that they might attract a financially settled man, their only chance of upward social mobility? The hidden feudal character of these two examples is the double standard for different social classes and the invisible, but thick line between them which allows no trespassing

The second book, Newer Ideals of Peace (1907), includes her observations from having lived for 18 years in a crowded multicultural area of immigrants from different nations and ethnic and religious orientations. She was able to observe empirically two different interaction patterns and ethical orientations. The first one is particularistic, respecting and aiding people who are like us and belong to us; the second one is universalistic, respecting and sharing what human beings have in common, aiding people who do not belong "to us" and strives for a universal ethic and peace for all as "manifestations of a newer humanitarianism" (p. 28, p. 30).

Thus, the long-term goal of peace building is to find social mechanisms which should finally lead to a universal law protection system "which dignifies also the weakest citizen and human being"- actually a formulation which anticipates not only the development of the League of Nations after World War I, but the Universal Declaration of Human Rights of the United Nations of 1948, after World War II. To support her thesis, she refers to Hobhouse, a historian, who writes: "A universal and lasting peace might be a vision, even an illusion, but nevertheless one can postulate the possibility of a concrete historical process, which is the development of international law and of morals, and voluntary arbitration based thereon", assuming the possibility of a voluntary juridical procedure and a court of justice. "International law should then be an equivalent with national law - a formalised expression of the rules of interaction and of reciprocal constraints which are considered necessary to protect people and the common good." (6f.) Thus, the immigration context offers the empirical condition to learn, practice and combine both orientations - respecting diversity, but confronting it with the claim for the recognition of the common characteristics of all human beings.

The third book, A New Conscience and an Ancient Evil (1912), is based on reports of the Juvenile Protective Association of Chicago, special investigations made by the association on dance halls, theatres, amusement parks, lake excursion boats, petty gambling, the home surroundings of 100 Juvenile Court children and the records of 4000 parents, Jane Addams writes: They "became to me a revelation of the dangers implicit in the city conditions and the allurements which are designedly placed around many young girls in order to draw them into an evil life." (p. ix) The "social evil" is not the prostitution itself, but the "sexual commerce permitted to exist in every large city ... wherein the chastity of women is bought and sold." (p. 9) Instead of a moral condemnation of the women (which almost never includes the men buying sexual services), she is impressed by the many diverse people for whom "the white slave traffic had become unendurable" (p. x). Remembering the liberation process of the black slaves in the USA, she develops first "An Analogy" (3-13) between the black slaves and the women caught in prostitution as "white slaves" and on this base an action plan of societal change with three overlapping phases:

During the first one, the obligation to provide shelter should dominate, information and counselling for every woman about her rights as a human being who wants to get out of the dependency from their exploiter. The black slaves used the "underground railroad" from the south to the northern states, 
having information where they could get safe shelter from their brutal prosecutors.

The second phase should have the goal of public consciousness raising about the life and working conditions of prostitutes in order to change two general public cultural assumptions which are responsible for the "persistent ignorance of the subject" (p. 11) by society. One is that prostitution is a natural fact reaching till the origins of humankind and thus cannot be changed. She notes as counter-facts wartime, colonisation and suppression by dominant populations, e.g. the winners of wars who assumed that they automatically have the "right" of sexual abuse of women. She also challenges the ideology that prostituted women enjoy it as much as the men do-which ignores that many women have to be made dizzy by alcohol. She reinterprets prostitution, a very economically lucrative, worldwide, organised business, as a societal and social fact of sexual domination in which women lose all their rights. Her hope was that the emotions which would be raised by the information about the "thousands of young girls, many of them still children, who are sacrificed to the "sins of the people' ought to made of value" would create a movement for collective action, leading to the third phase (p. 11).

The third phase was again an analogy to the abolition of slavery, namely to organise and make alliances in order to develop and influence legislation about trafficking, the extension of prostitution and its abuse. ${ }^{1}$ The "modification of legal codes regarding marriage and divorce, moral judgements concerning the entire group of questions centring about illicit affection between men and women are quite other questions which are not considered here" (p. 9). Although she notes that it would never be possible to eliminate all prostitution, just as one can never eliminate all murders, this was not an excuse for non-action. For her, social "progress is deeply indebted to a study of imperfections, and the counsels of despair, if not full of seasoned wisdom, are at least fertile in suggestion and a desperate spur to action. Sympathetic knowledge is the only way of approach to any human problem, and the line of least resistance into the jungle of human wretchedness must always be through that region which is most thoroughly explored, not only by the information of the statisticians (and scientists, $\mathrm{StB}$ ), but by sympathetic understanding" (p. 11).

Although all three books would deserve a much more detailed analysis, one can identify the following topics for theory development and education about social work and human rights: At the start of each book is what Addams called the

\footnotetext{
${ }^{1}$ It is important to remember that the Bill of Rights of 1789 was still a document of rights for white men. Only in the version of 1865-only 25 years before the opening of Hull House - we find an additional article 13 which forbids slavery, and in the version of 1870, a 15th article was added which guaranteed equality of all men citizens; the 19th article about women's suffrage was added in 1920. And it needed the Civil Rights Movement of the 1960 s to finally establish the full civil rights for black people in the constitution!
}

"jungle of human wretchedness" in a crowded slum where immigrants, political refugees and their families were hoping for a living and/or protection from political persecution and torture.

She succeeded in combining empathy, reflection, research, consciousness raising, direct individual help and collective social activism, but saw empathy as a precondition for "the identification with the common lot" (1902, p. 11).

She used the development and use of scientific research as counter-knowledge invalidating mainstream opinions and ideologies. Poverty, war, the sexual commerce with women, domination and violence, etc. were analysed on at least three theoretical levels: the sufferance of the individual, the ideological cultural codes cherished by the "public opinion" which are one of the causes that social problems are ignored without any feelings of moral guilt-left alone the violation of values such as equality, democracy, social justice, freedom, etc. The conception of theoretically based action-guidelines addressed the three different social levels: the individual and family level (first book); the community and international level (second book) and the individual, community, national (legislation) and international level.

In sum, the content of the books embraces all general themes in a nutshell which can serve as guidelines for the development of the curriculum "Social Work as (a) Human Rights Profession". We have seen these ideas come to be actualized in current work in the area of human rights (see Part II) (Staub-Bernasconi 2012a; 2015; 2016, see also www.mrma-berlin.de//2 These ideas are also present in the following statement of the IFSW:

"Human rights are inseparable from social work theory, values and ethics, and practice. Rights corresponding to human needs have to be upheld and fostered, and they embody the justification and motivation for social work action. Advocacy for such rights must therefore be an integral part of social work, ... ." (IFSW u. a.: 2000; Par. 24)

What this means for the profession is exemplified in three areas: first, the overlap between social work clients and the addressed individuals and groups by the UN, second the triple mandate of social work (described below) and third, the focus of the profession on social rights.

\footnotetext{
${ }^{2}$ The first master started 2002 in Berlin, especially for students in German-speaking countries; the second one started 2014 as International Master of "Social Work as a Human Rights Profession" at the Alice Salomon University of Applied Sciences.
} 


\section{Social Work Clients and Vulnerable Individuals and Groups as the Common Ground of the Tradition of Social Work and of Human Rights and the Necessity of a Triple Mandate of Social Work}

If one looks at the range of social problems and the involved clients and client populations of social work, one will detect that they are almost identical with what the UN defines as "vulnerable individuals and groups" in the conventions of the UN. There are documents about the poor and unemployed; discrimination against women; those in bondage; migrants and their families, political refugees; children and especially exploited ones as soldiers or as objects of pornography; human beings with disabilities, with different sexual orientations and gender identity; victims of racism, religious or political intolerance, human trafficking, war, torture and many others.

Vulnerability can be defined from two perspectives. The first perspective is the one from the individual: It refers to persons who

- Have the lowest or even no access to public resources, meaning education, jobs and income which allow a life standard which guarantees the satisfaction of their biological, psychic, social and cultural needs

- Have the least psychological and social capabilities to develop their human potential and the sources of well-being

- Have the lowest or no influence upon the conditions of their personal life as well as the conditions of public and political life to give them a direction which is in their favour

- Have no influence on the distribution of the gross national product and of wealth

In short, falsifying the societal discourses about the ability to succeed through individual efforts, they are not able to create and secure a safe existence according to the standards of "human dignity". The interests of these groups can be violated with using "only symbolic" power of negative labelling and stigmatising, and in addition, they can be used for the interests of those in power (see mainly Reichert 2003, p. 134).

From the perspective of society, vulnerable individuals and groups are especially suited as scapegoats for experienced or feared structural threats (downward social mobility, eroding social security in old age) and consequentially for politics of symbolic upgrading and the persuasion of superiority and on the other side ethnocentric disrespect and disdain for groups in an inferior power position. Yet, particular conditions must be met.

- Prejudice must already exist against particular individuals or groups before scapegoating develops

- The individuals must appear to be too weak to fight back successfully when attacked
- Finally, society must sanction (positively) the scapegoating and forms of homophobia, classism, racism, antisemitism, etc. in public or being institutionalised as structural violence in the norms, values and laws of a society (see Saenger, 1953, in Blumenfeld and Raymond, in: Adams et al. 2000, p. 24).

Many contributions about social work refer to a double mandate of help and control, the first one from the client, the second one from the organisation. Critical, and even more radical, social work tell us that the mainstream of social work, especially the one embedded in state welfare organisations, has only one answer to the suffering and problems of the described individuals and groups, namely control and repression according to a top-down mono-mandate of help as control. And many times the criticism is too "global" and "absolute" - with no respect for those who try hard, even at the risk of losing their job and their career, to change the policy inside of welfare organisations. Yet, social work as a profession has three mandates: the first one given by the clients, the second one by the state or agency as representatives of society and the third one by the organised profession itself. The third mandate legitimises relative professional autonomy, i.e. to make judgements about scientifically based interventions as well as ethical judgements in relation to its professional ethical code. Although this can be accompanied with many tensions, the skillful dealing with these three mandates is part of the competence of any profession.

The UN manual "Social Work and Human Rights" states clearly that if there is conflict between the organisation and the client, the support of and help to the client has priority (1992, p. 5). Introducing human rights in social work gives the profession not only the chance to criticise the mono-mandate, it requires great respect for what clients feel and think about their situation, according to what motivation and goals they would like to change it. While the social work community is partially still today discussing whether social work is a science-based profession, and if it has gone in the direction of inter-disciplinarity perhaps "too far or not far enough" (Brekke 2014), we can learn from the writings of Jane Addams at the end of the nineteenth century that one cannot renounce to scientifically based knowledge, meaning transdisciplinary descriptions, causes and consequences of social problems. Disciplinary knowledge is the base for "critical counter-knowledge" against culturally deep-rooted mainstream ideologies about social problems, and human dignity is the base of human rights and thus ethically and sciencebased action guidelines which may question considerably consensual mainstream ethical values and norms (StaubBernasconni 2016).

The third mandate can also include working without a mandate from society, in non-functioning social welfare states, in contexts of political conflict or failed states (Ramon 2008), 
and it legitimates the refusal of mandates from the state or private employers which violate human rights or blatantly dismiss scientific evidence and professional knowledge (see the second example in Part II). Claiming responsibilities for the whole domain of human rights is unrealistic, when one considers the scarce resources, and the relatively low societal status and power of social work. But the assumption of the following sections is that it has an important contribution to make to the domain and implementation of social rights.

\section{Social Rights as Central Topic of Social Work}

Although at the Vienna World Conference of 1993, 173 states declared solemnly that human rights are "universal, indivisible, interdependent and inalienable" (UN doc. A/CONF.157/ 23, Part I, para 5), one cannot overlook the fact that the civil and political rights are legalised and much more publicly discussed and monitored than social rights. In fact, the violation of freedom rights provokes a huge concerted protest of all kinds of human rights organisations and activists, social movements, NGOs and media accompanied by the demand for immediate intervention. Remember, for example, the protests concerning the imprisoned Chinese artist Ai Wei-Wei or the lawyer and human rights activist Chen. This comparison does not diminish or deny in any way the courage and great merits of these two and other personalities standing up individually against dictatorial, despotic regimes. Yet, since the end of the Cold War, millions of people died from povertycaused conditions, and each year, there are at least 18 million more-a number increasing with each economic crisis. A much larger number lives under conditions of lifethreatening poverty; for them, it is almost impossible to stand up for their interests and rights (Pogge 2008). Irene Kahn, former secretary general of Amnesty International, reminds us in her book The Unheard Truth. Poverty and Human Rights (2010) about the scandal of poverty and the big asymmetry, i.e. a hierarchy between freedom and social rights. The book is a plea to define poverty as a grave violation of human rights and thus to help empower the poor to claim their rights because liberty alone does not feed anyone (see also Reisch 2014).

\section{Part II: the European Context of Human Rights with a Special Look at Switzerland and Germany}

To have a detailed picture of how the national constitutions of each country integrate human rights, one should initiate the same analysis made by Wronka (1992) in comparing the Universal Declaration of Human Rights with US federal and state constitutions. The European context has, in addition to the regional European Declaration of Human Rights, an additional declaration called the European Charter of Social
Rights which was initiated by the working-class movement. Its articles are seen as the concretisation of freedom rights as social rights, assuming that freedom must be secured by freedom from poverty, meaning the right to decently paid work, housing, health, education and social security and the right of access to the information and decision mechanism at the working place, among other things.

To give an impression about the variety of formulations in national constitutions, I will provide just a short comparison between the three German-speaking nations. Germany shows two interesting differences between the Universal Declaration of Human Rights and the text of the post-1945 constitution called "Grundgesetz": Although its first article reads: "Human Dignity is untouchable", it was not possible to formulate a consensual definition of "Human Dignity" between religious, philosophical and representatives of secular ethics. This led to the decision to leave this admittedly very difficult concept undefined as "uninterpreted thesis". What followed from this are endless theological, philosophical, ethical and law-oriented debates about it till the position that one should place "human dignity" on the same level as the following specific articles.

Another characteristic of the German "Grundgesetz" is a separate or parallel law which secures the Catholic and Lutheran churches and welfare organisations (Caritas and Diakonie which control about $70 \%$ of the labour market for helping professions) the right for "self-governance" which means that they are allowed to recruit individuals of the same confession without being sanctioned for discrimination. This holds also for special moral laws about sexuality, marriage and divorce, etc. which do not conform with human rights. As a result of secularisation, the diminishing influence of the churches, and the growing number of migrants and refugees with very different ethnic and religious backgrounds, this formula gets - till now more clandestinely than openly - under attack.

Austria's constitution refers to a pure Republican notion without explicit reference to human dignity and rights in the text: "Austria is a democratic Republic. Its law is made by the people". The rest is a "blueprint" informing how the division of power has to function. The constitution of Switzerland starts with the preamble: "In the Name of God the Almighty" and mentions Human Dignity in article 7 and, most important in relation to the first example: Art. 26, Par. 1 states: "Individual Property is guaranteed".

Transitioning now to discuss poverty and the implementation of social rights in Europe by students of the Berlin Master "Social Work as Human Rights Profession", it is important to note that I am fully aware about the huge differences between poverty in "rich countries" of the Global North and poverty in the "poor countries" of the Global South and Asia. However, poverty remains an issue here as well. 
Social Rights as Main Focus of Social Work-Example I: the Case of the European Charter of Social Rights-a Project on the National Level of Switzerland

The European Social Charter of Social Rights is a project initiated by the European Commission in Brussels. It was ratified by a majority of the Parliament in 1961 as an element of international law, which guarantees the inhabitants of the signing nations a comprehensive range of social rights as binding law since 1996. In 2015, Switzerland had a population of 8,240,000 million and is known as one of, some would say, the richest society of the world. In spite of this fact or, probably better, due to it, it has only signed, but not ratified, the first version of the European Charter of Social Rights (ECSR) of 1965 and it neither signed nor ratified the revised Charter European Social Charter of 1996. With this state of affairs, it is in good company with Liechtenstein, San Marino and Monaco.

Four students (Bruno Keel, Stéphane Beuchat, Simone Greminger and Maria Valero), now alumni of the Berlin Master of Social Work and Human Rights, in 2008 decided to start a ratification campaign for the "European Charter of Social Rights" of 1996. Stéphane Beuchat became the secretary of the National Federation of Social Workers called Avenir Social. So the organisation, together with other engaged social workers as well as representatives of NGOs, unions and publicly known personalities, was able to sustain the campaign in a more powerful way. The leader, Bruno Keel, has a job as a social worker and thus works for the campaign in his free time.

The basic social problem(s) of the campaign is not only poverty but also the growing insecurity of the middle classes around social security, work according to the acquired competences and the securing of other social rights. On the cultural level, since about 1995, the political mainstream has succeeded in cutting the state finances with the argument that state services and especially the "social industry" (a new word in addition to social parasites, fictional disability, welfare tourists) is too expensive to maintain. The liberal party, together with a powerful populist nationalist party of the right, argues also on the cultural level, saying that the Social Charter destroys the freedom-right to individual property, individual entrepreneurship and thus the free market mechanisms securing social justice for all. For them, the still-growing gap between the lowest and huge incomes and fortunes, the lack of an income that allows to secure the fulfilment of human needs of about half a million working poor, the anxieties of the middle class to be dequalified after the age of 50 and the anticipation to have no social security in their older days are not problems (Mäder 2015). The real problems are the "social jealousy" of the people, the arbitrariness and eagerness of the state, a growing state budget and attacks upon the freedom of property as a human right. The culmination of all these is that the party of the national right plans to launch a political initiative to quit the European Declaration of Human Rights together with the "Social Charter". According to them, Switzerland has to get rid of the foreign laws imposed by foreign judges in Strasbourg. The diffusion of these ideas is so successful that even the people with the lowest income and social security level partially believe it.

\section{What Is Now the "Counter-Knowledge" to This Widely Shared Discourse?}

Scientific expertise about financial issues on the national and world levels postulates that there is plenty of money for financing all the actual social obligations including the ones coming from the European Social Charter (Chesney 2014). The cause which explains this puzzling paradox is the autonomisation of the "financial industry" as a worldwide social subsystem acting separately from the traditional economy and small businesses. Its purpose is to produce money out of money, which has been made possible by the invention of derivative instruments for the only purpose of worldwide speculative transactions. These instruments are so complex that the shareholders, as well as the bank managers, do not understand their functioning. Thus, a huge amount of money circulates almost exclusively in this nearly closed social subsystem and thus develops an enormous power first over the traditional economic system which produces "real goods" and second indirectly the financial situation of national and state economies. This all was possible on the base of the transfer of the human right to property - which was historically bound to the individual or individuals collaborating together as "natural persons"- to corporations defined as "legal persons". Thus, huge worldwide corporations are now also bearers of the human right of the "freedom of property" which become the base of an enormous concentration of capital. A stillgrowing class of managers represents today the biggest parallel society with its own private legal conflict-regulation system without any democratic legitimation (Bornschier 1983; Holzhey and Kohler 1983), but with an enormous influence upon the destiny of the economy and the further development of entitlements to social rights. And in addition, we have the additional paradox about fortunes of millionaires and billionaires who bequeath their fortune to their children without any individual performance and merits. Parallel to this, we have welfare recipients who are only entitled to welfare, if they fulfil all sorts of duties; even then the subsidies are at or under the level of the existential minimum, the so-called basic survival needs (Butterwegge 2015). 


\section{What Could Be Action Guidelines Following from This Analysis?}

The logical, yet actually highly unrealistic programmatic idea would be to mobilise for the "rolling back" of the unconditional constitutional guarantee of corporate property rights and/or for a considerable rising of the taxation for inherited income without merits. More "realistic" could be the integration of the following idea into a campaign for the ratification of the "Social Charter": Switzerland and most of the other countries could renounce to the taxation of their population if it would introduce an automatic tax of about $0.2 \%$ for each electronic payment. In 2012, the electronic payments reached the enormous amount of 1000 milliards of Swiss francs. A tax of 0.2 would generate 200 milliards which is over the 170 milliards of taxes which Switzerland got by the usual taxation in 2012! The idea is not new; but what is new compared with the "Tobin Tax", now called "Transaction Tax", is that Chesney can show that with the suggested taxation policy, no citizen would have to pay taxes anymore! (For details, see Chesney 2014, pp. 86-92; Bolliger 2013). Although it is a long-term vision, the argument could bring new ideas in the ideological blockage and resignation and perhaps raise considerably the chances for the success of the campaign about the ratification of the Social Charter. After 8 years, the project is now in the phase where the government has to formulate the decisive document for the decisive debate and vote of the parliament probably planned for this or next year. This project shows that one needs a very long breath, flexibility and high resistance to adverse political developments in order to stick to the shared goal.

\section{Social Rights as Main Focus of Social Work-Example II: the Case of Ignored Poverty in Germany}

Compared with the constitution in Switzerland which has in Art. 12 only a "Right to help in situations of need", the German "Grundgesetz" states in Art. 20 the following about the fundamental principles underlying its state structure: "The German Republic is a democratic and social state." The discussed examples below show the discrepancies between claim and reality around the topic of poverty. In addition, it shows how social workers as state employees can be involved in the violation of human rights and what the role of "critical social work" could be in such situations.

The relevant articles of the Universal Declaration of Human Rights are Article 22, social security, and Article 25, adequate standard of living, as well as Article 5 which states that "No one shall be subjected to ... degrading treatment or punishment."

These undergird the described projects which are an example for what I call "small scale consciousness-raising and action oriented research":
In the first project, extensive narrative interviews were conducted and analysed to answer the question What does it mean to live on 359 euro welfare in Berlin? (Gurzeler et al. 2009). This amount includes everything except the rent and the basic health insurance (one subway ticket costs at that time 2 euros; if one has to go to work, already 50 euros are gone just for transportation). Each day, one has to decide if one can satisfy the biological (hunger), psychological (e.g. information), social (e.g. meeting people, being a respected group member) or cultural (e.g. watching a movie or concert) needs at the detriment of other needs. It was found that after the 20th day of each month, for almost all interviewed individuals, there was no money for buying food. They then get food from a neighbour, go to a soup kitchen or search for food in containers. They do not socialise or attend a socio-cultural event, fearing being recognised as welfare recipients and thus being stigmatised in public. Having to pay 10 euros for the first visit of a medical service, they will not seek medical services, even for serious illnesses. All welfare recipients had debts which they could not pay back. After the interviews, the social workers tried to interest them to join a Citizen's Platform in Berlin which works in the community organising tradition of Saul Alinsky. All refused with the argument that for them it is much more important to know that what they had to say has been written down (given back) and transmitted to the United Nations.

A second project asked: "How welfare workers are treating their clients?" (Geier 2009). The chosen method was that of participant observation. A social worker accompanied clients to the welfare agencies, introduced herself to the officer and then observed the interaction between them and their clients. In almost all cases, the treatment violated all principles of interactional fairness and respect. In addition, the officer would arbitrarily refuse the money to which the clients were legally entitled. In one case, an employee even denied that the client had an invitation, although he could show him the official invitation letter. He disappeared saying that he is now on vacation. When the social worker wanted to know from the clients after the visit to the welfare centre if there was a difference between coming alone or being accompanied by a person (as a "visible" source of support), they did not see any difference.

There were cases where the observing social worker changed her role, breaking principles of research in order to avoid that the client would lose his apartment, room or shelter the same or next day because he was not able to pay the rent. Of course, the social worker reflected her dilemma between the professional ethic and the ethic of scientific research. Her conclusion was that she could justify her decision to intervene according to the principle: when in doubt, go for the rights of the client!

The third project started with the question: "What are the consequences when young people under 25 years have their 
welfare cut to Zero?"-a blatant human rights violation (Grießmeier 2009). The reasons for the legally legitimated cuts include not appearing at the agency upon invitation, not reading the relevant documents (which most youngsters, coming from different ethnic and language backgrounds, do not understand), refusing to give information about private topics, not cooperating in the search for a job, etc. The belief of politicians discussing the legislation about juvenile unemployment and poverty without any theoretical or research-based arguments (see Grießmeier 2011) is that the complete cut of all subsidies, meaning also health insurance, rent and often also gas, electricity, hot water and heating (if they are not living with their-often troubled - families), will have the positive effect that they quickly look for and have a job. In one case, a girl had a serious illness; the physician wanted to know first if she has health insurance. As she said no, he refused to accept her as patient.

The study showed that none of the interviewed young people were successful in getting a job and thus stopped looking for one. Most of them were depressed, having no hope or chance to improve their situation without help. Some showed some inclination to join a gang or to start a "career" as a prostitute. Confronting social workers with the consequences of their "professional help", they said that the youngsters always find a helping person-a friend, a grandmother, a street acquaintance, a shelter somewhere. Only one social worker admitted that it was a problem, namely when the young people still live at home: the cut of their part of welfare influences heavily the budget of the whole family. Yet, a constitutional state (Rechtsstaat) forbids "collective punishments". No social worker was conscious about the fact of the violation of human/social rights. Nevertheless, the study had the effect that the sanctions of $100 \%$ were not implemented anymore - due to the civil courage of the social manager of the social service.

Currently, there is no relevant or effective opposition from social work, which is a blatant violation of the professional mandate. The three studies were integrated in a UN Shadow Report as a parallel report to the fifth official state report of the German government referring to the Covenant about "Social Rights" (Allianz für wirtschaftliche, soziale und kulturelle Rechte in Deutschland 2011). It was a product of 20 NGOs working with different "vulnerable groups". The big Christian welfare organisations (Caritas and Diakonie) did not contribute to it. The students of the Berlin Master were the only ones who advocated for the then 6.5 million poor on social welfare. The answers given in the hearing to the members of the UN commission by the government officers were so problematic, uninformed and partially arrogant that the recommendations of the commission to the German government filled half a page of positive remarks, followed by over eight pages of recommendations and demands to initiate changes in different areas of economic, social and cultural rights. But what was really new in this document was a recommendation to the government to open a public discussion about the report and the explicit recommendation to the NGOs to organise a monitoring process about the implementation of the recommendations (Pact I, Art. 11) (Kiessling 2015).

\section{Conclusion}

The first project is situated on the national level on the base of the triple, more precisely autonomous third, mandate of the profession. To wait for a mandate from the state of Switzerland about the promotion of social rights is absolutely illusionary. The empirical "counter-knowledge" to the neoliberal ideological mainstream was not produced by the social workers. It was drawn from research about the world economy, the influence of the management class in big corporations, the publicly unperceived transfer of the human right to individual property to a "human right" of "legal persons" and its destructive effects upon the state budgets and democracy. The action-oriented knowledge can be found in literature about social movements, campaigning, alliance building, interviewing, dealing with media, but also, if necessary, the use of power sources - accompanied by a high portion of creativity to react to unexpected and adverse situations (Prasad 2011).

The second example links individual welfare recipients with the international UN level. What they say about their situation takes place in a country which is proud to be a "social" state. The social workers seem to have uncritically internalised the mono-mandate of the state-narrowed to "help as control". But in addition, they violate blatantly social rights. Existential resources have to be given unconditionally. What is needed here is a discussion about the difference between the legality and legitimacy of a law or law system - a reflection required by the third professional mandate. The "counter-knowledge" invalidating the neoliberal mainstream ideology of politicians and apparently internalised also by social workers has been produced by self-mandated "critical social workers." They were researching and acting outside of the welfare system and confronting the "insiders", also their superiors, with questions which partially made them change their practice. It could be further developed as a model of the division of labour between social workers.

Both projects show that in professional human rights work, three different knowledge orientations and logics have to be combined: the first one is theory and research asking for $s c i-$ entific descriptions and explanations about social problems and empirical human rights violations; the second one is normative knowledge about national and international law systems according to the logic of subsumption of facts under a law and the Code of Ethics; and the third one is an action theory of individual and social change - if necessary including the change of laws or the development of new ones. To 
renounce to the first knowledge dimension makes social work a job of client administration and of self-righteous, ineffective "moral entrepreneurs".

I close with a second look at history which invites us to remember the following passages in the documents of the French Declaration of Human Rights of 1789: Men are born and remain free and equal in rights; social distinctions may be based only upon general usefulness. "It says that there can be a "just inequality", but only if it has a socially useful dimension. Art. 4 of the same declaration formulates "Liberty consists of the power (!) to do whatever is not injurious to others; ... ." Olympe de Gouges writes in her Declaration of the Rights of the Woman and Citizen (1791) for which she was killed by the guillotine: "Liberty and justice consist of restoring all (giving back) that belongs to others; ...." What a sentence which ties social justice to liberty and forces us - facing the actual stream of war and economic refugees to remember: They are here because we were there and still are there!

\section{References}

Adams, M., Blumenfeld, W. J., \& Castaneda, R. (2000). Readings for diversity and social justice. An anthology on racism, anti-semitism, sexism, heterosexism, ableism, and classism. London: Routledge.

Addams, J. (1902). Democracy and social ethics. New York: Macmillan.

Addams, J. (1907). Newer ideals of peace. New York: Macmillan.

Addams, J. (1912). A new conscience and an ancient evil. New York: Macmillan.

Allianz für wirtschaftliche, soziale und kulturelle Rechte in Deutschland (2011). Parallelbericht zum 5. Staatenbericht der Bundesrepublik Deutschland zum Internationalen Pakt über wirtschaftliche, soziale und kulturelle Rechte (ICESCR).

Bolliger, F. (2013). Reinvent the system-Microsteuer auf Gesamtzahlungsverkehr. Zürich: Aktiengesellschaft.

Bornschier, V. (1983). Eigentum und Verfügungsmacht, In: Holzhey/ Kohler (Hg):161-197

Brekke, J. S. (2014). A science of social work, and social work as an integrative scientific discipline: have we gone too far, or not far enough? Research on Social Work Practice, 24(5), 517-523.

Butterwegge, C. (2015). Hartz IV und die Folgen. Auf dem Weg in eine andere Republik. Weinheim/Basel: Beltz.

Chesney, M. (2014). Vom Grossen Krieg zur permanenten Krise. Der Aufstieg der Finanzaristokratie und das Versagen der Demokratie. Zürich: Versus.

Geier, K. (2009). Die Würde des Menschen ist unantastbar. Wie werden die Ansprüche von ALG2-Empfängern von den Jobcentern in Berlin unter menschenrechtlichen Aspekten umgesetzt?, Projektbericht, Masterstudiengang ZPSA, Berlin.
Grießmeier, N. (2009). Hartz IV-Sanktionen in München, Projektbericht, Masterstudiengang ,Soziale Arbeit und Menschenrechte“, Projektbericht Masterstudiengang. Berlin: ZPSA.

Grießmeier, N. (2011). Der disziplinierende Staat: Eine kritische Auseinandersetzung mit $100 \%$-Sanktionen bei Arbeitslosengeld IIEmpfängern aus der Sicht der Sozialen Arbeit und der Menschenrechte, Masterarbeit am Zentrum für Postgraduale Studien Sozialer Arbeit Berlin. Berlin: ZPSA.

Gurzeler, S., Ortelli, A., \& Rohleder, D. (2009). Leben mit Hartz IV. Reicht die Höhe des ALG II als soziokulturelles Existenzminimum aus, um die biopsychosozialen Bedürfnisse von Menschen in Einpersonenhaushalten zu befriedigen?, Projektbericht, Masterstudiengang. ZPSA Berlin

Holzhey, H., \& Kohler, G. (1983). Eigentum und seine Gründe, Ein philosophischer Beitrag aus Anlass der schweizerischen Verfassungsdiskussion. Bern/Stuttgart: Haupt.

Kahn, I. (2010). The unheard truth. Poverty and human rights. London/ New York: Norton.

Kiessling, R. (2015). Die UN-Empfehlungen zum 5. Staatenbericht Deutschlands zum Sozialpakt - Möglichkeiten zur Verbesserung des Diskussionsprozesses der Bundesregierung Deutschlands gemäss Punkt 38 am Beispiel des Menschenrechts auf "ausreichende Unterbringung" im Freistaat Sachsen, Projektbericht, Masterstudiengang. ZPSA, Berlin.

Mäder, U. (2015). Macht.ch, Rotpunktverlag, Zürich

Pogge, T. (2008). World poverty and human rights. Cambridge/UK: Polity Press.

Prasad, N. (2011). Mit Recht gegen Gewalt-Die UN-Menschenrechte und ihre Bedeutung für die Soziale Arbeit. Budrich: Opladen/ Farmington Hills/MI.

Ramon, S. (Ed.). (2008). Social work in the context of political conflict. Birmingham: Venture Press.

Reichert, E. (2003). Social work and human rights. New York: Columbia University Press.

Reisch, M. (Ed.) (2014). The Routledge international handbook of social justice. New York.

Staub-Bernasconi, S. (2012a). Human rights and their relevance for theory and practice. In L. M. Healy \& R. J. Link (Eds.), Handbook of international social work. Human rights, development, and the global profession (pp. 30-37). Oxford/New York: Oxford University Press.

Staub-Bernasconi, S. (2012b). Partnering with the United Nations-human rights and social work, celebration of the „United Nations World Social Work Day“ March 26th, 2012, Geneva (Presentation of ,The Global Agenda for Social Work and Social Development Commitment to Action").

Staub-Bernasconi, S. (2015). „Newer ideals of peace“-how Jane Addams' critical look at peace theories shaped the content of The International Congress of April, 1915 in the Hague. In G. Franger \& C. Lohrenscheit (Eds.), Peace building-gender-social work (pp. 49 73). Verlag: Paulo Freire.

Staub-Bernasconni, S. (2016). Human rights and social work. In R. Benaprés, V. Atria, \& P. Molina (Eds.), Reader on social work. Santiago: University of Chile. LOM editiones.

Wronka, J. (1992). Human rights and policy in the $21^{\text {st }}$ century. Lanham/ New York/London): University Press. 